\title{
Marica Nadlišek Bartol in njeno literarno delo
}

\author{
Silvija Borovik \\ Univerza v Mariboru, Filozofska fakulteta, Koroška cesta 160, SI - 2000 Maribor, \\ silvija.borovnik@uni-mb.si
}

\begin{abstract}
Pisateljica Marica Nadlišek Bartol je bila prva urednica lista Sloven$k a$, ki velja za prvi slovenski ženski časopis, v okviru katerega so pričele objavljati tudi druge slovenske pisateljice, publicistke in prevajalke. Nadliškova je vzpodbujala njihovo literarno ustvarjanje ter jih tako nacionalno kot feministično osveščala. Njen edini roman Fata morgana iz 1.1898 je izhajal v nadaljevanjih v Ljubljanskem zvonu. Pričujoče besedilo analizira njegovo vlogo $v$ sobesedilu porajajoče se književnosti slovenskih avtoric s preloma iz 19. v 20. stoletje. Izkaže se, da je ta roman rušil prenekatero tabuizirano vprašanje svoje dobe, zlasti tista, ki so se nanašala na položaj in vlogo žensk v osebnem in družbenem življenju.
\end{abstract}

Die Schriftstellerin Marica Nadlišek Bartol war die erste Redakteurin der ersten slowenischen Frauenliteraturzeitschrift Slovenka. In dieser Literaturzeitschrift veröffentlichten auch die anderen slowenischen Schriftstellerinnen, Publizistinnen und Übersetzerinnen. Marica Nadlišek unterstützte ihr literarisches Schaffen, sie verbreitete aber auch sowohl die feministischen als auch die slowenischen Nationalideen. Ihr einziger Roman Fata morgana erschien in einzigen Fortsetzungen in der Zeitung Ljubljanski zvon. Diese literaturwissenschaftliche Studie analysiert seine Rolle im Kontekst erst entstandener Literatur der slowenischen Autorinnen am Jahrhundertwende (19.-20. Jhd). Dieser Roman detabuisierte manche Fragen seiner Zeit, besonders diejenigen, die im Zusammenhang mit der Lage und Rolle der Frauen im persönlichen und gesellschaftlichen Leben waren.

Ključne besede: Marica Nadlišek Bartol, časopis Slovenka, prve slovenske pisateljice, roman Fata morgana.

Schlusselworter: Marica Nadlišek Bartol, Literaturzeitschrift Slovenka, die ersten slowenischen Schriftstellerinnen, Roman Fata Morgana 
K razvoju slovenske ženske književnosti konec 19. in na začetku 20. stoletja je pripomogel predvsem list Slovenka, ki je 1897. leta pričel izhajati v Trstu kot priloga Edinosti vsako drugo soboto kot »glasilo slovenskega ženstva«. Oblikovali sta ga dve urednici, Marica Nadlišek Bartol in Ivanka Anžič Klemenčič.

Prva, Marica Nadlišek (rojena 1967 v Kolonji, pozneje poročena Bartol), je bila učiteljica v tržaškem predmestju. Slovenko je urejala tri leta (1897-1900). $\mathrm{V}$ Trstu je bila angažirana v politiki in kulturi. Sodila je med prve slovenske intelektualke, ki so bile prav učiteljice. Goriško učiteljišče je namreč omogočalo takrat še redkim slovenskim ženskam izobrazbo za intelektualni poklic, pri čemer so se ponujale možnosti še za literarno ustvarjanje. A učiteljišče v Gorici, ustanovljeno 1. 1870, je bilo takrat še nemško, tako da se je Nadliškova tam srečala tudi z germanskim omalovaževanjem Slovencev, pozneje pa še z italijanskim fašizmom v Trstu in okolici. Do 1. 1899 je poučevala pri Svetem Ivanu. Na vprašanje, zakaj se prve slovenske pisateljice-intelektualke pojavijo prav v Trstu, ne pa na primer v središčni Ljubljani, lahko odgovorimo z dejstvom, da je bil Trst na prelomu stoletja v primerjavi z Ljubljano zaradi svoje mediteranske širine in odprtosti, v kateri so se srečevale različne kulture, svetovni nazori in vplivi, v tem smislu in seveda tudi zaradi trgovskih ambicij mnogo bolj raznoliko mesto, tako da ni naključje, da je toleriral tudi prve ženske feministične ideje in literarne ambicije. Ko pa se je Nadliškova poročila, se je morala odpovedati svojemu učiteljskemu poklicu, saj so bila taka tedanja poklicna pravila. Veljal je namreč nekakšen celibat za učiteljice. Če so si izbrale družino, Nadliškova pa je rodila kar sedem otrok, so se morale svojemu učiteljskemu poklicu odpovedati. Žal se je Nadliškova polagoma odpovedala tudi literarnemu ustvarjanju. Tako kot mnoge druge ženske tedanjega časa je morala zakopati svoj sicer izraziti in že uveljavljeni literarni talent. Zaradi pritiskov italijanskih nacionalistov se je 1. 1919 z družino umaknila v Ljubljano, kjer pa skoraj ni več pisala. Umrla je 3.1.1940.

Nadliškova je bila od prvega literarnega nastopa 1889 poleg Pavline Pajkove prva pomembna pisateljica Ljubljanskega zvona, v katerem so objavljala takrat že uveljavljena moška pisateljska imena, ugled pa si je pridobila še s podlistki, polemikami in članki v Slovenskem svetu, Edinosti in Slovenskem narodu (Boršnik 1962, Butollo 1994, Borovnik 1995). Bila je tudi ena prvih slovenskih intelektualk, ki so si služile kruh s poklicnim delom. Zavedala se je zapostavljenega položaja slovenskih žensk in čutila predvsem njihovo zaostalost v izobrazbi. Zato velja za njihovo prvo sistematično osveščevalko in prosvetiteljico. List Slovenka je namreč pod njenim uredništvom pričel objavljati tudi tekste, ki so se nanašali na neenakopraven položaj žensk in moških v družbi, ta besedila pa so želela načrtno vzgajati ženske tudi kot bralke domače, slovenske književnosti. Nadliškova si je namreč prizadevala, da bi takrat sicer še redke slovenske bralke otresla nemškega kulturnega vpliva in srčno jih je navduševala za literarno ustvarjanje v slovenskem jeziku. Pri tem ji je moralno podporo nudil Slovanski svet, čigar utemeljitelji in sodelavci (Podgornik, Celestin, Hostnik) sodijo med prve slovenske izrazitejše borce za ženske pravice. Tem prizadevanjem se je pridružila še visokošolska Vesna. Napredne slovenske 
ženske so idejo lastnega časopisa z navdušenjem sprejele, a prve sodelavke in sodelavce si je morala Nadliškova šele poiskati in jih vzgojiti. O tem, da je bilo prebijanje ledu na tem področju težavno opravilo, pričajo tudi dejstva, da je marsikatera ženska svoje tekste v Slovenki objavljala pod moškim imenom, zelo pogosto pod psevdonimom, da pa so svoje prispevke v Slovenki pod psevdonimom objavljali tudi nekateri sicer že uveljavljeni slovenski pisatelji. Tako so ravnali najbrž zato, ker si niso hoteli prislužiti očitkov, da so »feministi«. Izraz feminizem je namreč še daleč v dvajseto stoletje vseboval vse lastnosti psovke, bil je zmerljivka in oznaka za »nepotrebna družbena gibanja«. V času, ko je pričela ustvarjati Marica Nadlišek, je zrcalil zlasti strah predstavnikov katoliške Cerkve, da bo časopis Slovenka vzgojil "pretirano emancipirane žene«, ki bodo zanemarjale skrb za družino in seveda zlasti za moškega. Tako njihovo poklicno delo kakor kakršnokoli umetniško ustvarjanje je bilo nezaželeno, ženske, ki so vstopale na dotlej skrbno varovana moška področja, pa so zasmehovali in jih globoko podcenjevali. O tem pričajo številni zapisi v tedanjem slovenskem katoliškem tisku, npr. v Domu in svetu ter drugje. Obe urednici Slovenke, tako Nadliškova kot pozneje Anžičeva, ki velja za prvo slovensko novinarko, sta se morali spoprijemati z mnogimi konzervativnimi očitki na račun svojega uredniškega, pisateljskega in publicističnega dela, povezanega z ženskim vprašanjem na Slovenskem.

$\mathrm{V}$ pogumen in docela samostojen spopad se je Nadliškova spustila s profesorjem in ravnateljem v goriškem bogoslovju ter poznejšim škofom Antonom Mahničem, ustanoviteljem in urednikom časopisa Rimski katolik, ki je veljal za strahospoštljivo avtoriteto. Vmešaval se je v vsa področja slovenskega javnega življenja, zlasti še v literaturo, kjer je zaviral sleherno napredno misel. Mahnič je v Rimskem katoliku večkrat objavil grobo podcenjevalna stališča, ki so se nanašala na vlogo žensk v umetnosti ter jasno izražal prepričanje, da ženska na tem področju nima kaj iskati in da naj raje molči, ostane poslušna gospodinja ter žrtvujoča se žena in mati. Mlada Marica Nadlišek pa si je upala polemizirati z njegovimi nazadnjaškimi stališči in se mu upreti. Njene polemike z Mahničem izražajo pisateljičino svobodnjaštvo.

Nadliškova se je zavzela za umetniško svobodo, in sicer v članku Naš literarni boj (Edinost 1896, št. 140). V Slovenki je obsojala nestrpnost slovenske duhovščine do poezije Simona Gregorčiča. Tega znanega pesnika je celo prosila, naj prevzame urejanje pesniškega dela Slovenke, k čemur se pesnik sprva ni dal nagovoriti, pozneje pa je na to pristal. Od pomembnejših pesnikov je za Slovenko pisal Anton Medved, v njej je občasno objavljal tudi Anton Aškerc, znana pa je bila še Cankarjeva naklonjenost temu listu. Sicer pa je Slovenka veljala bolj za literarno vadnico, medtem ko so avtorji svoje pomembnejše pesmi objavljali v Ljubljanskem zvonu. Pri prevodni literaturi se je Nadliškova odločala najraje za rusko, predvsem za Puškina in Lermontova. Kot urednica pa je pogrešala dobro izvirno leposlovno prozo. Tej želji je skušala prisluhniti Zofka Kveder, ki je v Slovenki v nadaljevanjih objavljala svoj začetniški roman iz študentskega življenja z naslovom Študentke. Kljub raznoliki strukturi Slovenke, ki je skušala ugoditi različnim bralnim interesom, pa se temu listu 
pozna, da je bila njegova urednica predvsem pisateljica, ki se zanima za sodobna literarna vprašanja. Čeprav je sama pripadala realizmu, je dopuščala napoved nove romantike in dekadence, a oboje je zavračala. Prav tako so se feministična vprašanja $\mathrm{v}$ času njenega urednikovanja šele pričela pojavljati na straneh tega lista, v resnici razcvetela pa so se šele pod vodstvom druge urednice, Ivanke Anžič, ki so jo bolj od literarnih zanimala socialna vprašanja. Obe urednici pa sta poudarjali pomen slovenske narodne zavesti za vsakršen napredek in kulturni razvoj. Pri tem sta se naslanjali na tedanje napredno časopisje, na Slovenski svet, Slovenski narod in Edinost.

Časopis Slovenka pod uredništvom Marice Nadlišek je bil namenjen tako preprostejšim kot tudi zahtevnim bralkam. Da pa si mora le-te šele pridobiti, se je urednica zavedala, o čemer pričajo njeni uvodniki, pa tudi njeni jezikovni nasveti, saj so se morale slovenske ženske izražanja in branja v slovenščini šele naučiti. O tem, da se je na področju pravice do uveljavljanja žensk v umetnosti in v življenju bil hud boj, pričajo številne polemike, ki sta jih obe urednici, pozneje tudi Anžičeva, vodili na svojih straneh. Predsodki v zvezi s tem so bili namreč trdno zakoreninjeni. Slovenka je zato kot vzor prinašala številna poročila o tem, kakšna je vloga ženske v sodobnem svetu, navajala je primere iz člankov v tujem tisku, seveda predvsem zato, da bi osvestila slovenske ženske in nasprotnike njene zgodnje emancipacije. Pri tem ni zanemarljivo, da so Slovenkine sodelavke poudarjale skrb za narodnozavedni značaj, saj so bili na prelomu stoletja predvsem višji slovenski sloji povsem ponemčeni. Redke slovenske izobraženke pa so literaturo prebirale predvsem v nemščini. Vloga Marice Nadlišek Bartol in njenega časopisa Slovenka je bila tako na marsikaterem področju zares pionirska. Žal pa ta časopis ni izhajal zelo dolgo in je imel le petsto naročnic. Vznemirljive in napredne ideje obeh urednic so se v resnici utegnile le zasejati. Kljub vsemu sta k sodelovanju pritegnili številne sodelavke in sodelavce, med pesniškimi imeni v Slovenki pa prevladujejo ženske - Vida Jeraj, Fanica Vovk, por. Jeraj, Marica Strnad, Kristina Schuller, Zorana Tojanšek. Med pripovednicami se je prav v Slovenki prvič pojavila pozneje plodovita pisateljica Zofka Kveder, ki se je nekaj časa, preden se je podala na šolanje v Švico in Prago, zadrževala tudi v Trstu.

Marica Nadlišek kot pisateljica in urednica je po kulturnem obzorju daleč presegala svoje okolje in seveda tudi čas, v katerem je začenjala literarno ustvarjati. Bila je samouk, sama se je naučila prebirati italijansko, francosko, rusko in nemško literaturo. Zgledovala se je delno po evropskem sentimentalnem romanu, delno pa po prozi svojega vzornika in učitelja Janka Kersnika. Kersnik, piše Boršnikova (Boršnik 1967: 28-29), je veljal za osrednjo osebnost slovenskega realističnega pripovedništva, listu Slovenka pa je pomenil ne le največjo oporo kot leposlovec, temveč tudi kot kritik in vzgojitelj pripovednega naraščaja. V Marici Nadlišek je prepoznal literarno nadarjenost ter jo vzpodbujal, da je sledila realističnim zgledom iz domače in tuje književnosti. Pisateljica je v svojih literarnih besedilih ostajala zvesta temam in motivom iz domačega mestnega in malomestnega okolja, ki ga je sama doživljala in ga najbolje poznala. Zlasti tesno se je čutila povezana z ženskimi usodami in njihovimi 
družbenimi vlogami, katerih del je bila. Marja Boršnik, ki je med prvimi slovenskimi literarnimi zgodovinarji raziskovala delo te dolgo pozabljene tržaške pisateljice, je poudarila, da je Nadliškova že pol stoletja pred Govekarjem, ki velja za osrednjega predstavnika slovenske naturalistične smeri, upovedovala tudi socialne motive in da je v tržaškem proletariatu našla veliko gradiva za prikazovanje velikomestne bede. Toda izrazito občutljivo se je vživljala v propadajoče slovensko meščanstvo ter slikala anomalije iz njegovega življenja, podobno kot pol stoletja pozneje Ljubljančanka Mira Mihelič (1912-1985).

Marica Nadlišek je svoje prvo literarno delo, črtico z naslovom Moja prijateljica, poslala Ljubljanskemu zvonu, ki jo je urednik Fran Levec 1889 objavil na priporočilo Janka Kersnika. Z njim si je Nadliškova namreč dopisovala od leta 1883, srečala pa sta se šele 1889 na Bledu, kar je opisala v črtici Slike in sličice iz življenja 11 (Ljubljanski zvon, 1896). Svoje prijateljevanje s Kersnikom in njegov literarni vpliv je tematizirala pozneje v svojih spominih Iz mojega življenja, 1927, največ njene proze pa je izšlo v Ljubljanskem zvonu (16 naslovov, zadnji 1901). Njena zgodnejša proza je še črtica Iz življenja mlade umetnice (1890), ki pa že vsebuje osrednje motive večine avtoričinih poznejših del. V ospredju je namreč motiv mlade učiteljice, ki je nesrečna zaradi socialnih ovir na svoji poklicni poti ter zaradi ujetosti v vsakdanje družinsko in zakonsko življenje. Odlične opise Trsta in njegove okolice srečamo nadalje v besedilu Na obali (1891), sledita pa mu še prozni besedili Strte peruti (1894) o razočaranju mlade mestne učiteljice, ki mora poučevati na vasi, in Pod streho (1897), prav tako o učiteljici, ki se kot izobraženka iz nižjega sloja sooča s tržaško visoko družbo ter s problemi slovenskega in italijanskega delavstva. V časopisu Slovenka je Nadliškova objavila le malo svojih besedil, med redkimi npr. novelo Intrigant.

Edini roman Marice Nadlišek Bartol je pod naslovom Fata morgana (1898) izhajal v nadaljevanjih v Ljubljanskem zvonu, pomenljivo pa je, da ga je avtorica objavljala pod moškim psevdonimom, namreč kot Evgen Štefanič. O nastanku romana piše Mihael Glavan v članku (Ljubezenska) sreča je le fata morgana (Delo, 25. 3. 1998) Avtor navaja, da sta bila Viktor Bežek, tedanji urednik Zvona, in Nadliškova v pisnih stikih, včasih pa sta se srečevala tudi osebno. Marica Nadlišek mu je obljubila roman v nadaljevanjih, urednik pa jo je k pisanju priganjal, saj je bila pisateljica zelo zaposlena in za literarno delo ni imela veliko časa. Bila je namreč učiteljica, urednica Slovenke, dopisnica Edinosti in gonilna sila slovenskih žensk v Trstu. Zato je roman pisala dobesedno sproti. Avtorica sama se je tako zavedala določenih pomanjkljivosti $\mathrm{v}$ romanu, a uredniku je njen sentimentalni realizem ugajal, zato se romanu $\mathrm{v}$ nadaljevanjih ni hotel odpovedati. Očitno pa je bilo tudi to, da je Maričino pisanje imelo določeno občinstvo.

Snov za svoj roman je pisateljica vzela iz podeželsko-mestnega življenja Trsta in okolice, nekatera dogajališča pa je namestila na Dunaj, ki ji je služil kot primer velemesta, njegove brezdušnosti, narejenosti in tudi pokvarjenosti. V ljubezenska razmerja je zapletla več mladih parov, od katerih nekateri izvirajo iz dokaj premožnih meščanskih družin, vsi pa si utirajo pot v življenje, nekateri z izobraženostjo in s trdim delom, drugi pa z ukanami in s špekulacijami. V 
središču romanesknega dogajanja, ki ima kar nekaj stranskih zgodbenih pramenov, je družina Rodič s hčerko Dano, ki jo oblegajo različni snubci. Toda dekle, vzgojeno v verskem zavodu, se za nobenega ne navduši. Po obisku pri teti na Dunaju, kjer doživi družabno življenje v velemestu ter je priča nekaj ljubezenskim in zakonskim peripetijam, zavrne veseljaškega snubca Periča, a tudi sicer je Dunaj s svojim salonskim spakovanjem ne očara. Dana bi se bila morala privaditi mestnemu življenju, a mlado dekle vidi v njem le številne anomalije. Ne le odnosi med ljudmi, ki se srečujejo v salonih, temveč tudi komunikacija med njimi je izumetničena, kaže pa na preziranje Danine materinščine, to je slovenščine. Marica Nadlišek je podobno kot pozneje Mira Mihelič podrobnosti teh salonskih pogovorov, v katerih se nemščina meša $\mathrm{s}$ slovenščino, spretno vnesla v svoj roman. Videti je, da se osebe slovenskega izvora svojega jezika sramujejo in da se jim zdi nemščina bolj primerna za občevanje v višji družbi. Ves ta »bedasti svet« v Dani vzbuja odpor, tako da komaj čaka na vrnitev domov, na slovensko podeželje. V tej zgodbi je tako že od vsega začetka poudarjen pomen slovenske narodne zavesti, s čimer je Nadliškova ostajala zvesta tistemu, o čemer je sicer pisala v Slovenki. Drug idejni poudarek, ki ga je Nadliškova vpletla v svoj roman, pa je v pomenu domače, slovenske literature, za izobrazbo in življenje slovenskih žensk. Dana ima namreč prijateljico Olgo, le-ta pa Dano pogosto navdušuje nad branjem slovenske literature. Z Dano torej ne klepeta le o dekliških skrivnostih srca, temveč jo vzgaja predvsem kot bralko.

V nasprotju z Dunajem je Trst v romanu Fata morgana omenjen kot »prijazno mesto ob morju«. Povsem nove in zagotovo vznemirljive za tisti čas pa so romaneskne debate o svobodni ljubezni in zakonu. Ta tema je bila prav tako pogosto obravnavana na straneh časopisa Slovenka, saj je bilo na prelomu stoletja še v navadi, da so se zakoni sklepali na osnovi finančnih in rodbinskih interesov, ne pa zaradi ljubezni med mladimi pari. Slovenka je na tem področju rušila to tabuizirano vprašanje in se upirala tradiciji, zato ni naključje, da je temo v svoj roman vnesla tudi njena urednica, pisateljica Marica Nadlišek. Tretja vznemirljiva in za prelom stoletja zagotovo pregrešna tema, ki si jo je upala oblikovati Nadliškova, pa je bila ljubezen med duhovnikom in žensko. Dana v njenem romanu se namreč doma zaljubi v mladega kaplana, iz dogajanja pa je prav dobro razvidno, da ljubezen med njima ne ostane le platonska, temveč da ji jo duhovnik tudi vrača. Erotični prizori v romanu so sicer le nakazani, vendar jasno prisotni (kot poljubljanje in telesni stik). Za natančnejše slikanje pa Nadliškova očitno ni imela poguma. Iz vsega naštetega je zdaj razumljivo, zakaj je pisateljica objavljala svoj roman pod moškim imenom - saj bi si kot ženska in učiteljica lahko prislužila nepredvidljive posledice v osebnem življenju.

Romanu Fata morgana se sicer pozna, da je bil pisan sproti in v nadaljevanjih za objavo v časopisu, saj so njegova poglavja včasih neusklajena, povezovalna fabulativna nit neredko neutemeljeno pretrgana, osrednje dogajanje je pravzaprav šibko, vse pa se vrti okrog praznih klepetov v salonih, ob meščanskih omizjih itd. Podob iz narave skorajda ni, osebe so tudi redko prikazane v akciji, kot dejavni posamezniki. Fizično so slabo izrisane, njihova zunanjost je le 
omenjena. Moški v romanu so izobraženci (profesor, zdravnik, trgovec), ženske pa ne premorejo niti izobrazbe niti lastnih poklicev. Videti je, da so vzgajane zgolj za poroko, službo moškemu in družini. Tudi same drugih ciljev navadno nimajo. Med ženskimi liki pa izstopa lik matere samohranilke Zdenke, ki se potem, ko jo je zapustil ljubimec, z njunim otrokom odloči za samostojno pot. Tudi to je nov motiv v literaturi, ki so jo pisale ženske do Marice Nadlišek. Ta ženski lik je namreč oblikovan z naklonjenostjo, poudarjeni sta njegova trdnost in odločenost, da si z delom ustvari lastno življenje, in sicer ne glede na to, da je v družbi zaradi nezakonskega materinstva očitna izločenka in zavrženka. Navedene so tudi govorice iz okolice, ki menijo, da je Zdenka »preveč emancipirana« - ker je samostojna, ker ne sprejema miloščine in ker si z lastnim delom, to je s šivanjem in z vezenjem, služi kruh zase in za otroka. Zdenka je tudi edina ženska v romanu, ki dela, vse druge pristajajo na to, da jih finančno vzdržujejo moški. Ženski pogovori v romanu so nadalje naslikani plehko in površno, nanašajo se na vsakdanje teme in ljubezenske peripetije, dobro zgrajeni pa niso niti pogovori med moškimi, ki se prav tako vrtijo le okrog žensk, redkeje okrog gospodarstva ali političnih tem.

Toda osrednja fabulativna os se odvija na temo ljubezni med kaplanom in Dano. Dana goji do njega pristna ljubezenska čustva, on pa je v tej zvezi bolj preračunljiv. Zaveda se namreč, da bo prestavljen v drug kraj in ločitev od ljubljene ženske ga ne skrbi. Danina ljubezen pa je močna in pristna, o čemer priča tudi njeno erotično sanjarjenje: »Da, celo naslajala se je ob teh spominih.« (Fata morgana, str. 192)

Kolikšna drznost je bilo zapisati kaj takega za Marico Nadlišek, lahko razumemo v kontekstu mahničevskega preganjanja Gregorčičeve ljubezenske poezije in številnih napadov na Slovenko in prva znamenja emancipacijskega gibanja okrog nje. Nikakor pa seveda ni bilo v navadi, da bi o ljubezenskem ali erotičnem življenju pisala ženska. Nadliškova je tudi na tem področju prebijala trdo skorjo konzervativne tradicije. Da pa bi poravnala Danin greh, jo pisateljica zaradi neuslišane ljubezni pošlje v samostan, medtem kot njenega ljubljenega in ljubečega duhovnika le premesti v drugo župnišče. Tam bo, je ironično nakazano v romanu, lahko iskal novih ljubezenskih zvez.

Z usodami nosilnih literarnih likov v svojem romanu je Nadliškova opozorila na dvojna merila, ki so v družbi njenega časa veljala za moške in ženske. Njena Zdenka je zaradi svobodne ljubezni kaznovana s težkim in finančno negotovim življenjem, Dana pa se zaradi grešne in neizpolnjene ljubezni zapre v samostan. Oba moška lika, Danin kaplan in Zdenkin meščanski ljubimec, neobremenjeno živita dalje. Kakršnokoli moraliziranje okolice v zvezi z dejanji moških likov ni omenjeno. Tako Zdenkina kot Danina ljubezenska sreča sta bili očitno le fata morgana, namišljeni in kratkotrajni privid. Zadnji del romana sestavljajo pisma, kar kaže na to, da je Marica Nadlišek poznala in s svojim literarnim delom nadaljevala tradicijo evropskega pisemskega romana.

Nadarjena pisateljica Marica Nadlišek je morala umolkniti zaradi težkih družinskih in družbenih razmer. Rodila je sedem otrok, od katerih sta dva umrla. Njena družina je bila v času fašističnega nasilja nad Slovenci in zaradi prve 
svetovne vojne izpostavljena pomanjkanju, tako da je morala vse svoje moči posvetiti duhamornemu boju za preživetje. Marja Boršnik je v svojem članku o njej zapisala, da se je morala Nadliškova celo z nahrbtnikom zatekati po hrano na Kranjsko, da je reševala svojo uradniško družino lakote. Tragedija njenega življenja, je zapisala Boršnikova, pa je značilna tragedija milijonov žena, ki morajo žrtvovati svoje intelektualne talente za družinsko skupnost (Boršnik 1967: 33). Boršnikova je o Nadliškovi pisala kot o zakopanem literarnem talentu. In ker pisateljica svojih tekstov za časa življenja ni zbrala v samostojno knjigo, je njeno delo pričenjalo počasi toniti v pozabo. Na srečo pa se to ni povsem zgodilo, in sicer prav po zaslugi Marje Boršnik, France Buttolo, Katje Mihurko Poniž in še nekaterih drugih, nenazadnje tudi pisateljice Ivanke Hergold, ki je roman Fata morgana leta 1998 pripravila za izid v samostojni knjigi. S tem je poudarila pomen Marice Nadlišek Bartol za zgodovino in razvoj slovenske književnosti, zlasti tiste, ki so si jo v avtoričinem času še zelo plaho in poredko upale pisati ženske.

Marica Nadlišek Bartol torej ne sme biti znana le po tem, da je njen tretjerojeni sin Vladimir Bartol postal pomemben slovenski pisatelj 20. stoletja, avtor številnih novel in cenjenega romana Alamut, temveč zaseda v zgodovini slovenske književnosti samostojno in pomembno mesto. Vladimir Bartol je o svoji materi pisal v delu Mladost pri Svetem Ivanu (Primorski dnevnik 1955-1956, ponatis Ljubljana, 2003). Zavedal se je materine veličine, predvsem pa njene žrtve. Zapisal je, da ve, kako visoko ceno je plačala njegova mama s tem, da se je odpovedala svojemu literarnemu ustvarjanju takrat, ko se je šele pričenjala razvijati.

\section{VIRI IN LITERATURA}

Silvija BOROVNIK, 1995: Pišejo ženske drugače? Ljubljana: Mihelač.

Marja BORŠNIK, 1962: Študije in fragmenti. Maribor: Obzorja. 115-127.

--, 1967: Ob stoletnici rojstva Marice Nadlišek. Jezik in slovstvo 4, 107-108.

Franca BUTTOLO, 1994: Ponosna Slovenka in na literaturo strastno navezana Tržačanka. Delo, Književni listi, 1. 9. 1994, 13.

Minka GOVEKAR, 1926: Marica Nadlišek Bartol. Ženski svet 1926, 129-133.

Mihael GLAVAN, 1999: (Ljubezenska) sreča je le fata morgana. Delo, 25. 3. 1999.

Miran HLADNIK, 1981: Slovenski ženski roman v 19. stoletju. Slavistična revija 3, 259-296.

Katja MIHURKO PONIŽ, 1999/2000: Pripovedna besedila slovenskih pisateljic - sodobnic Zofke Kveder. Jezik in slovstvo 45/4, 121-132.

Marija PIRJEVEC, 2001: Tržaška knjiga. Ljubljana: Slovenska matica.

Marica NADLIŠEK BARTOL, 1998: Fata morgana. (Spremna beseda Ivanka Hergold). Trst: Mladika. 


\section{MARICA NADLIŠEK BARTOL UND IHR LITERARISCHES WERK}

Zur Entwicklung der Literatur slowenischer Autorinnen verhalf vor allem die Literaturzeitschrift Slovenka, welche am Jahrhundertwende in Triest erschien. Marica Nadlišek Bartol war die erste Redakteurin dieser Zeitschrift und zugleich auch eine der ersten slowenischen Schriftstellerinnen des 19. Jahrhunderts. Sie war auch die erste slowenische Feministin. Sie bemühte sich, dass die slowenischen Frauen auf Slowenisch anstatt auf Deutsch lesen könnten, so schrieb sie die Kurzgeschichten und Novellen auf Slowenisch. Bei ihrem literarischen Werk war sie der scharfen Kritik der konservativen katholischen Kreisen ausgesetzt. Diese Kreise unterschätzten das literarische Schaffen der Frauen und propagierten ihre Rolle vor allem in der Familie, nicht aber auch in der Kunst. Marica Nadlišek Bartol schrieb neben der Kurzprosa auch einen Roman mit dem Titel Fata Morgana (1898), in welchem sie die Rolle der bürgerlichen Frau analysiert. Sie detabuisierte manche Fragen, welche sich auf die Rolle der Frau in dieser Zeit beziehen und bewieß, dass sie die Tradition der europäischen Frauen- und Briefroman kannte. Sie war die Mutter des bekannten slowenischen Schriftstellers Vladimir Bartol, verdient aber ihre eigene bedeutende Stelle in der slowenischen Literaturgeschichte. 